\title{
Editorial: Advances and Challenges of RNAi Based Technologies for Plants
}

\author{
Bruno Mezzetti ${ }^{1 *}$, Matthias Fladung ${ }^{2}$ and Jeremy Sweet ${ }^{3 *}$ \\ ${ }^{1}$ Department of Agriculture, Food and Environmental Sciences, Università Politecnica delle Marche, Ancona, Italy, \\ ${ }^{2}$ Thünen-Institute of Forest Genetics, Grosshansdorf, Germany, ${ }^{3}$ Environmental Consultant, Cambridge, United Kingdom
}

Keywords: gene silencing (siRNA), cross kingdom, pathogen control, biosafety, sustainable agriculture

\section{Editorial on the Research Topic}

\section{Advances and Challenges of RNAi Based Technologies for Plants}

In this Research Topic, the focus is on recent research and developments in the use of RNAi techniques to protect plants. Cross kingdom effects of RNA expressed in plants primarily for pathogen control are discussed by Schaefer et al. in Cross-Kingdom RNAi of Pathogen Effectors Leads to Quantitative Adult Plant Resistance in Wheat.

Pest as well as pathogen control is considered in Plant miRNA Cross-Kingdom Transfer Targeting Parasitic and Mutualistic Organisms as a Tool to Advance Modern Agriculture by Gualtieri et al..

Bachman et al. consider aspects of their research on dsRNA expressed in maize/corn for

\section{OPEN ACCESS}

Edited and reviewed by:

Fernando Ponz,

Instituto Nacional de Investigación y Tecnología Agroalimentaria

(INIA), Spain

${ }^{*}$ Correspondence: Bruno Mezzetti

b.mezzetti@univpm.it Jeremy Sweet

jeremysweet303@aol.com

Specialty section:

This article was submitted to

Plant Biotechnology,

a section of the journal

Frontiers in Plant Science

Received: 13 March 2021

Accepted: 07 April 2021

Published: 07 May 2021

Citation:

Mezzetti B, Fladung M and Sweet J

(2021) Editorial: Advances and

Challenges of RNAi Based

Technologies for Plants.

Front. Plant Sci. 12:680242.

doi: 10.3389/fpls.2021.680242 root worm beetle control in Sequence-Activity Relationships for the Snf7 Insecticidal dsRNA in Chrysomelidae.

The efficiency and efficacy of a system for lepidopteran control is discussed in Comparative Analysis of Chitin SynthaseA dsRNA Mediated RNA Interference for Management of Crop Pests of Different Families of Lepidoptera by Rana et al..

The potential for plants to express RNA viruses which can infect both plants and insects but which are pathogenic in their insect vectors is considered as a strategy for vector insect control in The Use of Engineered Plant Viruses in a Trans-Kingdom Silencing Strategy Against Their Insect Vectors by Kolliopoulou et al..

The biosafety assessments of these and other host induced gene silencing (HIGS) systems are discuss in Biosafety of GM Crop Plants Expressing dsRNA: Data Requirements and EU Regulatory Considerations by Arpaia et al..

Exogenous application of dsRNA (SIGS) for pest and pathogen control is an attractive alternative but is confronted with several problems related to application, uptake, persistence, and efficacy. In Barriers to Efficient Foliar Uptake of dsRNA and Molecular Barriers to dsRNA Activity in Plant Cells, these are discussed by Bennett et al..

Uslu et al. describe studies of high pressure spraying to improve efficacy in High-Pressure-Sprayed Double Stranded RNA Does Not Induce RNA Interference of a Reporter Gene.

In relation to virus control, Tabein et al. discuss The Induction of an Effective dsRNA-Mediated Resistance Against Tomato Spotted Wilt Virus by Exogenous Application of Double-Stranded RNA Largely Depends on the Selection of the Viral RNA Target Region.

Research on control of a major insect pest is reviewed in Validating the Potential of DoubleStranded RNA Targeting Colorado Potato Beetle Mesh Gene in Laboratory and Field Trials by Petek et al..

These papers give an insight into the many areas of research on the potential applications for RNAi for crop protection. Some applications are being commercialized while others are 
at earlier stages of research (Taning et al., 2020a). The Editors believe that applications of HIGS and SIGS can make major contributions to sustainable and integrated crop protection and support "Green" systems for intensification of agricultural production as advocated in UN Sustainability Development Goals and by FAO, EU, and many national governments (Mezzetti et al., 2020; Taning et al., 2020b). The editors would like to acknowledge the opportunity provided by Frontiers for publishing these papers and thank the authors for their contributions. The editors and many of the authors are members of the iPlanta COST action CA 15223 and further information on iPlanta and publications produced by iPlanta are available at https://iplanta.univpm.it/.

\section{REFERENCES}

Mezzetti, B., Smagghe, G., Arpaia, S., Christiaens, O., Dietz-Pfeilstetter, A., Jones, H., et al. (2020). RNAi: what is its position in agriculture? J. Pest Sci. 93, 1125-1130. doi: 10.1007/s10340-020-01238-2

Taning, C. N. T., Arpaia, S., Christiaens, O., Dietz-Pfeilstetter A., Jones, H., Mezzetti, B., et al. (2020a). RNA-based biocontrol compounds: current status and perspectives to reach the market. Pest Manage. Sci. 73, 841-845. doi: $10.1002 /$ ps.5686

Taning, C. N. T., Mezzetti, B., Kleter, G., Smagghe, G., and Baraldi, E. (2020b). Does RNAi-based technology fit within EU sustainability goals? Trends Biotechnol. 12. doi: 10.1016/j.tibtech.2020.11.008. [Epub ahead of print].

\section{AUTHOR CONTRIBUTIONS}

All authors listed have made a substantial, direct and intellectual contribution to the work, and approved it for publication.

\section{ACKNOWLEDGMENTS}

This publication is produced by the COST Action iPlanta, supported by COST (European Cooperation in Science and Technology). COST is a funding agency for research and innovation networks. Our Actions help connect research initiatives across Europe and enable scientists to grow their ideas by sharing them with their peers. This boosts their research, career and innovation.

Conflict of Interest: The authors declare that the research was conducted in the absence of any commercial or financial relationships that could be construed as a potential conflict of interest.

Copyright (c) 2021 Mezzetti, Fladung and Sweet. This is an open-access article distributed under the terms of the Creative Commons Attribution License (CC BY). The use, distribution or reproduction in other forums is permitted, provided the original author(s) and the copyright owner(s) are credited and that the original publication in this journal is cited, in accordance with accepted academic practice. No use, distribution or reproduction is permitted which does not comply with these terms. 